\title{
PELATIHAN METODOLOGI PENELITIAN BAGI GURU SLTP NEGERI 26 KOTA BATAM
}

\author{
Raymond \\ Universitas Putera Batam \\ Email: darayaja@gmail.com
}

\begin{abstract}
The purpose of this program is how to increase the knowledge and understanding of teachers at SLTP Negeri 26 Batam about research methodologies and improve the ability of teachers at SLTP Negeri 26 Batam in making research proposals specifically research class actions. The method used is to give lectures and presentations on the theory of research methodology to teachers at SLTP Negeri 26 Batam and provide a tutorial on how to make research proposals ranging from title making to research methodology. The results achieved in this program are participants having knowledge about making action research proposal. In addition, participants have also been able to understand the scope of the research proposal and the Participants have also been able to make research proposals specifically classroom action research.
\end{abstract}

Keywords: Training, Research Methodology, Classroom Action Research

\begin{abstract}
Abstrak. Tujuan dari program ini adalah Bagaimana meningkatkan pengetahuan serta pemahaman guru di SLTP Negeri 26 Batam tentang metodologi penelitian serta meningkatkan kemampuan guru di SLTP Negeri 26 dalam membuat proposal penelitian khususnya pebnelitian tindakan kelas. Metode yang digunakan ialah dengan memberikan ceramah serta pemaparan tentang teori metodologi penelitian kepada para guru di SLTP Negeri 26 Kota Batam serta memberikan tutorial bagaimana membuat proposal penelitian mulai dari Pembuatan judul hingga metodologi penelitian, Hasil yang dicapai dalam program ini adalah para peserta memiliki Pengetahuan tentang pembuatan proposal penelitian tindakan. Selain itu peserta juga telah dapat memahami mengenai ruang lingkup dari proposal penelitian dan para Peserta juga telah dapat membuat proposal penelitian khususnya penelitian Tindakan kelas
\end{abstract}

Kata kunci : Pelatihan, Metodologi Penelitian, Penelitian Tindakan Kelas

\section{PENDAHULUAN}

Guru adalah pendidik profesional dengan tugas utama mendidik, mengajar, membimbing, mengarahkan, melatih, menilai, dan mengevaluasi peserta didik pada pendidikan anak usia dini jalur pendidikan formal, pendidikan dasar, dan pendidikan menengah (Undangundang Nomor 14 Tahun 2005 tentang guru dan dosen).

Peranan guru sangat penting dalam dunia pendidikan karena selain berperan mentransfer ilmu pengetahuan ke peserta didik, guru juga dituntut memberikan pendidikan karakter dan menjadi contoh karakter yang baik bagi anak didiknya. Kompetensi guru merupakan kemampuan (melaksanakan tugas) yang dilandasi oleh pengetahuan, keterampilan dan sikap kerja untuk menyelesaikan pekerjaan tertentu. Kompetensi merupakan pengetahuan, keterampilan dan nilai-nilai dasar yang direfleksikan dalam kebiasaan berfikir dan tindakan.

Kompetensi guru harus dimiliki oleh seorang pendidik untuk dapat menjalankan profesinya. Tugas pokok guru adalah merencanakan dan melaksanakan proses pembelajaran, melakukan bimbingan dan pelatihan, serta melakukan penelitian. Adapun hak dan kewajiban guru, meliputi:

1. Penghasilan dan jaminan kesejatraan sosial yang pantas dan memadai.

2. Penghargaan sesuai dengan tugas dan prestasi kerja

3. Pembinaan karier sesuai dengan tuntutan pengembangan kualitas

4. Perlindungan hukum dalam melaksanakan tugas dan hak atas hasil kekayaan intelektual, dan

5. Kesempatan untuk menggunakan sarana, prasarana, fasilitas pendidikan untuk menunjang kelancaran pelaksanaan tugas.

6. Pendidik dan tenaga kependidikan berkewajiban memperoleh:

7. Menciptakan suasana pendidikan yang bermakna, menyenangkan, kreatif, dinamis dialogis. 
8. Mempunyai komitmen secara profesional untuk meningkatkan mutu pendidikan.

9. Memberi teladan dan menjaga nama baik lembaga, profesi, dan kedudukan sesuai dengan kepercayaan yang diberikan kepadanya.
Berdasarkan data dari Badan Pusat Statistik kota Batam tenaga pengajar yang terdaftar untuk berbagai tingkat di kota Batam adalah sebagai berikut :

Tabel 1 Jumlah tenaga pengajar Di Kota Batam

\begin{tabular}{llc}
\hline No & Jenis Sekolah & Jumlah tenaga pengajar \\
\hline $\mathbf{1}$ & TK & 1.943 \\
\hline $\mathbf{2}$ & SD & 4.618 \\
\hline $\mathbf{3}$ & SLTP & 3.182 \\
\hline $\mathbf{4}$ & SLTA & 1.765 \\
\hline Total & & 11.508 \\
\hline
\end{tabular}

Dengan total 11.508 pengajar di Kota Batam, banyak upaya yang dilakukan oleh pemerintah dalam meningkatkan kualitas pendidikan di Kota Batam. Upaya peningkatan kualitas pendidikan diwujudkan dalam bentuk penataran tenaga pendidikan, bantuan buku-buku dan media pelajaran, pengembangan kurikulum, peningkatan metode dan pendekatan mengajar, dan sebagainya.

Salah satu komponen pendidikan yang terkait langsung dengan proses pembelajaran yang perlu segera diperbaharui adalah pola pikir dan kemampuan guru. Faktor ini dapat memberikan pengaruh langsung terhadap hasil pendidikan. Penguasaan materi dan metode pembelajaran merupakan persyaratan mutlak untuk meningkatkan mutu pendidikan (Sujarwo, 2010), lebih lanjut salah satu upaya peningkatan kualitas guru yang telah dilaksanakan, adalah dengan mengembangkan berbagai penelitian yang berkaitan dengan pendidikan. Namun berdasarkan survey yang telah dilakukan banyak diantara guru belum memiliki kompetensi yang memadai, terutama dalam hal mendesain pembelajaran, maupun penelitian, untuk itu para guru sangat membutuhkan pembekalan dalam bentuk berbagai pelatihan khususnya dalam bidang metodologi peneliti yang membahas berbagai aspek penelitian beserta penerapannya khusunya dalam pembuatan penelitian tindakan kelas.

Objek pengabdian masyarakat kali ini adalah SLTP Negeri 26 Batam. SLTP ini didirikan pada tanggal 01 September 2006, diatas lahan seluas $5000 \mathrm{M}^{2}$ di daerah Komplek Perum. Rindang Garden, Batu Aji. Saat ini SLTP Negeri 26 Batam dipimpin oleh Hj. Rafe'Ah, S.Pd dan telah memiliki tenaga pengajar kurang lebih 30 orang dan pada survey yang telah dilakukan oleh Tim pengabdi Universitas Putera Batam, Salah satu permasalah yang dihadapi para guru di SLTP
Negeri 26 Batam adalah sulitnya para guru dalam melakukan penelitian sebagai salah satu sarana dalam pengembangan kapasitas guru untuk itu tujuan utama dari kegiatan ini adalah Bagaimana meningkatkan pengetahuan serta pemahaman guru di SLTP Negeri 26 Batam tentang metodologi penelitian dan Bagaimana meningkatkan kemampuan guru di SLTP Negeri 26 dalam membuat proposal penelitian khusunya penelitian tindakan kelas.

\section{METODE PELAKSANAAN}

\section{Metode Yang Ditawarkan}

Untuk memperoleh manfaat dari pengabdian ini serta dapat diimplementasikan, maka metode yang ditawarkan dalam pengabdian ini adalah sebagai berikut:

1. Langkah 1 (Metode ceramah)

Pengabdi memberikan ceramah dan pemaparan tentang teori metodologi penelitian kepada para guru di SLTP Negeri 26 Kota Batam

2. Langkah 2 (Metode Tutorial)

Pengabdi akan memberikan pelatihan bagaimana membuat proposal penelitian mulai dari Pembuatan judul hingga metodologi penelitian, selain itu akan para peserta akan diberikan bimbingan tentang gambaran umum dalam pembuatan proposal penelitian

3. Langkah 3 (Metode Diskusi)

Peserta pelatihan akan diberikan
kesempatan untuk mendiskusikan
permasalahan yang dihadapi dalam
pembuatan proposal penelitian.

\section{Evaluasi pelaksanaan kegiatan}

Kegiatan pelatihan Metodologi penelitian di SLTP Negeri 26 ini akan dievaluasi agar diketahui seberapa jauh keberhasilan dari kegiatan pelatihan ini, berikut disajikan tabel 3.1 
evaluasi dalam pelatihan metodologi penelitian ini :

Tabel 2 Evaluasi dalam pelatihan metodologi

\begin{tabular}{lll}
\hline \multicolumn{1}{c}{ Tujuan } & Indikator ketercapaian & Tolak ukur \\
\hline $\begin{array}{l}\text { Peserta termotivasi membuat } \\
\text { proposal penelitian }\end{array}$ & $\begin{array}{l}\text { Peserta mau Membuat proposal } \\
\text { penelitian }\end{array}$ & $\begin{array}{l}\text { Peserta yang mau membuat } \\
\text { proposal penelitian mengangkat } \\
\text { tangan }\end{array}$ \\
\hline $\begin{array}{l}\text { Peserta mampu terampil } \\
\text { dalam membuat proposal } \\
\text { penelitian }\end{array}$ & $\begin{array}{l}\text { Peserta mampu membuat judul, } \\
\text { latar belakang, landasan teori } \\
\text { dan metodologi penelitian }\end{array}$ & $\begin{array}{l}\text { Peserta memiliki proposal } \\
\text { penelitian }\end{array}$ \\
\hline
\end{tabular}

\section{Keberlanjutan dari hasil kegiatan}

Keberlanjutan dari hasil kegiatan pelatihan pembuatan proposal penelitian di SLTP Negeri 26 ini antara lain:

1. Seluruh peserta mampu membuat proposal penelitian

2. Peserta mampu menghasilkan penelitian yang diharapkan dapat menunjang sistem pendidikan di Kota Batam

Peserta yang berpartisipasi dalam program pelatihan ini, diharapkan kedepannya tidak hanya berasal dari lingkungan SLTP negeri
26 saja namun dari beberapa guru dari sekolah lain dalam tingkatan yang berbeda

\section{HASIL DAN PEMBAHASAN}

Berdasarkan hasil pelatihan kepada Guru SLTP Negeri 26 Kota Batam, saya bersama teman-teman dosen lain telah melakukan beberapa hal yang mana dari hasil pelatihan tersebut Guru SLTP Negeri 26 Kota Batam dapat membuat Proposal penelitian sendiri. secara garis besar hasil pelatihan ini dapat dijelaskan sebagai berikut:

Tabel 4.1 Pelaksanaan Kegiatan

\begin{tabular}{|c|c|c|c|}
\hline No & Waktu & Kegiatan & Pengisi Kegiatan \\
\hline 1 & $08.00-08.15$ & $\begin{array}{l}\text { Pembukaan (MC) } \\
\text { Serta Sambutan }\end{array}$ & 1) Raymond, S.E., M.Sc. \\
\hline 2 & $08.15-12.00$ & Acara Inti : & \\
\hline & 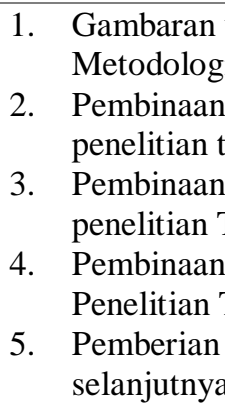 & $\begin{array}{l}\text { Im tentang } \\
\text { nelitian tindakan kelas } \\
\text { teri } 1 \text { (karakteristik } \\
\text { akan kelas ) } \\
\text { teri } 2 \text { ( Merencanakan } \\
\text { lakan Kelas) } \\
\text { teri 3( Format Usulan } \\
\text { lakan kelas) } \\
\text { gas pertemuan }\end{array}$ & 2) Raymond, S.E., M.Sc. \\
\hline
\end{tabular}

Pelaksanaan Pelatihan dilaksanakan pada hari Sabtu, 27 Agustus 2017 pukul 13.00 sampai dengan 15.30 diawali dengan pembukaan serta sambutan yang disampaikan oleh dan langsung dilanjutkan pada penyampaian materi pertama oleh Raymond, SE., MSc.

Pada pelatihan kali ini sesi pertama Topik pertama disampaikan oleh Raymond, SE., MSc, berkaitan tentang pembahasan karakteristik dari penelitian tindakan kelas materi disampaikan dalam rentang waktu kurang lebih 180 menit, topik selanjutnya disampaikan oleh Raymond, SE., MSc berkaitan dengan merencanakan penelitiaan tindakan kelas, materi ini disampaikan dalam rentang waktu kurang lebih 180 menit, Topik ketiga disampaikan oleh Raymond, SE., MSc yang menyampaikan format usulan penelitian tindakan kelas, materi ini juga disampaikan dalam rentang waktu kurang lebih 60 menit, materi terakhir lebih di fokuskan pada diskusi dan tanya jawab. Dari keseluruhan pertemuan pengabdian dari pertemuan ini dapat disimpulkan bahwa Guru SLTP Negeri 26 Kota Batam sudah memahami cara membuat proposal penelitian tindakan kelas, hal ini berbeda dengan pertemuan pertama dimana para Guru SLTP Negeri 26 Kota Batam menganggap bahwa proposal penelitian tindakan kelas, adalah sesuatu yang sulit, susah, dan membingungkan. Hingga setelah tim pengabdi memberikan pelatihan proposal penelitian tindakan kelas secara berangsur angsur berubah dimana Peserta sangat antusias ingin membuat proposal penelitian tindakan kelas. 
Berdasarkan hasil pelatihan kepada Guru SLTP Negeri 26 Kota Batam, ada beberapa outpul yang positif yang diperoleh dari pelatihan metodologi penelitian pada Guru SLTP Negeri 26 Kota Batam. Pertama para guru memahami berbagai metodologi dalam sebuah penelitian, kedua berdasarkan simulasi yang telah dilakukan para guru telah dapat menyusun proposal penelitian tindakan kelas yang akan dikembangkan menjadi sebuah penelitian. secara garis besar hasil pelatihan hal ini dapat dijelaskan sebagai berikut, Pelaksanaan pelatihan yang dilaksanakan pada 27 Agustus 2017, dimana

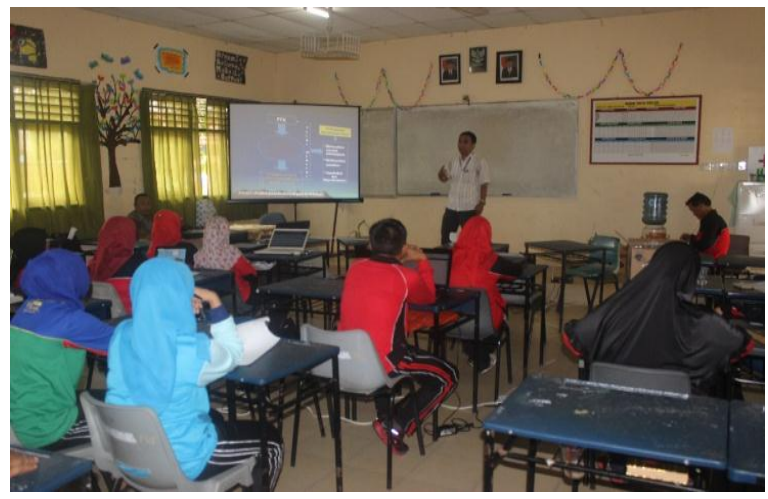

Gambar 1. Pembukaan Kegiatan Pelatihan

\section{SIMPULAN DAN SARAN}

Berdasarkan pengabdian yang telah dilakukan maka dapat diambil beberapa kesimpulan dan saran yang dianggap perlu, hal ini dimaksudkan supaya dapat menjadi pembelajaran bagi pengabdi, obyek pengabdian

Berikut adalah beberapa kesimpulan yang dapat diambil berdasarkan kegiatan pengabdian (pelatihan) yang telah dilakukan, diantara adalah sebagai berikut:

1. Meningkatnya Pengetahuan Guru SLTP Negeri 26 Kota Batam tentang pembuatan proposal penelitian.

2. Guru SLTP Negeri 26 Kota Batam juga telah dapat memahami mengenai ruang lingkup dari proposal penelitian

3. Guru SLTP Negeri 26 Kota Batam telah dapat membuat proposal penelitian

Berikut adalah beberapa saran yang dianggap perlu berdasarkan kegiatan pengabdian (pelatihan) yang telah dilakukan sebagai berikut:

1. Sebaiknya penyuluhan dan diskusi seperti ini dilaksanakan secara berkala.

2. Sebaiknya semua peserta sudah hadir tepat waktu (sebelum acara dimulai) jadi tidak ada peserta yang datang diawal, ditengah atau bahkan diakhir acara sehingga materi yang disampaikan tidak diulang-ulang. materi yang disampaikan adalah menyampaikan karakteristik penelitian kelas, merencanakan penelitian tindakan kelas, hingga dilanjutkan pada sesi terakhir mengenai format usulan penelitian tindakan kelas, setelah itu barulah peserta mulai memiliki bayangan dan gambaran terhadap apa itu penelitian tindakan kelas dan tata cara menyusunnya. Pemberian pelatihan ini juga meliputi pelatihan kemampuan para perserta secara bertahap dalam membuat proposal penelitian tindakan kelas, sehingga para peserta tahu dan memahami bentuk dari proposal penelitian tindakan kelas.

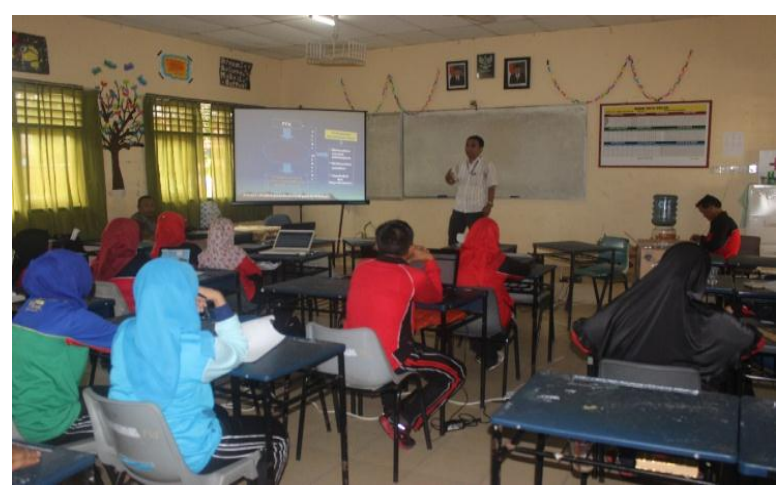

Gambar 2. Kegiatan Kegiatan Pelatihan

3. Kedepan jumlah Sekolah yang mengikuti pelatihan proposal penelitian bisa meningkat sehingga dengan adanya pelatihan ini diharapkan dapat membantu para guru dalam menangani berbagai permasalahan Khusunya yang berkaitan dengan pembuatan proposal penelitian.

\section{UCAPAN TERIMAKASIH}

Ucapan terimakasih disampaikan kepada 1) Guru SLTP Negeri 26 Kota Batam, yang telah bersedia meluangkan waktunya dalam kegiatan pengabdian ini 2) Kepada Sekolah SLTP Negeri 26 Kota Batam yang telah memfailitasi kegiatan pelatihan ini, 3) Kepada LPPM universitas Putera Batam yang telah mendanai kegiatan pelatihan metodologi kepada Guru SLTP Negeri 26 Kota Batam.

\section{DAFTAR PUSTAKA}

BPS. (2014). Batam dalam Angka. Batam: BPS.

Republik Indonesia. (2005). Undang-Undang

Nomor 14 Tahun 2005 tentang Guru dan

Dosen. Lembaran Negara RI Tahun

2005. Sekretariat Negara. Jakarta.

Sujarwo. (2010). Peranan Guru Dalam

Pemberdayaan Siswa. Dinamika

pendidikan, 